The University of Maine

DigitalCommons@UMaine

Maine History Documents

Special Collections

Fall 1890

\title{
A Contribution to Passamaquoddy Folk-lore
}

J. Walter Fewkes

Follow this and additional works at: https://digitalcommons.library.umaine.edu/mainehistory

Part of the History Commons

This Article is brought to you for free and open access by DigitalCommons@UMaine. It has been accepted for inclusion in Maine History Documents by an authorized administrator of DigitalCommons@UMaine. For more information, please contact um.library.technical.services@maine.edu. 


\section{THE JOURNAL OF}

\section{AMERICAN FOLK-LORE.}

VoL. III. - OCTOBER-DECEMBER, I890. - No. XI. [by J.watter Eewkes]

\section{A CONTRIBUTION TO PASSAMAQUODDY FOLK-LORE.}

THE study of aboriginal folk-lore cannot reach its highest scientific value until some method is adopted by means of which an accurate record of the stories can be obtained and preserved. In observations on the traditions of the Indian tribes, the tendency of the listener to add his own thoughts or interpretations is very great. Moreover, no two Indians tell the same story alike. These are sources of error which cannot be eliminated, but by giving the exact words of the speaker it is possible to do away with the errors of the translator.

I believe that the memory of Indians for the details of a story is often better than that of white men. There may be a reason for this, in their custom of memorizing their rituals, stories, and legends. The Kāklan, a Zuñi ritual, for instance, which is recited by the priest once in four years, takes several hours to repeat. What white man can repeat from memory a history of equal length after so long an interval?

Phonetic methods of recording Indian languages are not wholly satisfactory. It is very unlikely that two persons will adopt the same spelling of a word never heard before. Many inflections, accents, and gutturals of Indian languages are difficult to reduce to writing. Conventional signs and additional letters have been employed for this purpose, the use of which is open to objections. There is need of some accurate method by which observations can be recorded. The difficulties besetting the path of the linguist can be in a measure obviated by the employment of the phonograph, by the aid of which the languages of our aborigines can be permanently perpetuated. As a means of preserving the songs and tales of races which are fast becoming extinct, it is, I believe, destined to play an important part in future researches.

In order to make experiments, with a view of employing this 
I spent several days at Calais, while collecting traditions with the phonograph, and also visited Pleasant Point, where I made the acquaintance of some of the most prominent Indians, including the governor. Most of them speak English very well, and are ready to grant their assistance in preserving their old stories and customs. The younger members of the tribe are able to read and write, and are acquainted with the ordinary branches of knowledge as taught in our common schools. I should judge from my own observations that the language is rapidly dying out. The white women who have married into the tribe have generally acquired the language more or less perfectly. In their intercourse with each other, Indians make use of their own language.

In taking these records with the phonograph I had an interesting experience. The first time I met Noel Josephs, I greeted him after the Zuni fashion. I raised my hand to his mouth, and inhaled from it. He followed in identically the same manner in which a Zuñi Indian would respond. I asked him what it meant. He said that it was a way of showing friendship. He remembered that, when he was a boy, a similar mode of greeting was conmon among Indians. ${ }^{1}$ Mrs. Brown recalled having seen a similar ceremony after she was received into the tribe. The meaning of this similarity I leave to others to conjecture. In a legend mentioned by Mrs. Brown concerning a game of "All-tes-teg-enuk," played by a youth against an old man, the latter, who has magic power, has several times regained his youth by inhaling the breath of his young opponent. $^{2}$

\section{THE SNAKE DANCE.}

The Passamaquoddies, no doubt, in old times, had many clances, sacred and secular. Some of these were very different from what they now are, and in consequence it is not easy to recognize their meaning. Indians declare that in their youth dances were much more common. Possibly some of these will never be danced again. That the Micmacs, neighbors of the Passamaquoddies, had dances in which elaborate masks were worn, seems to be indicated by pictographs found on the rocks in Nova Scotia. Mrs. Brown has in her possession a head-band made of silver, similar to those worn in ancient times on festive occasions, and probably at dances. It was not necessarily a badge of a chief. In excavations made at East Machias, an Indian was found with a copper head-band and the rem-

1 My surprise at this coincidence was very great, but I confess that I was also interested to hear from the lips of my Indian friend, at parting, the familiar Italian word, "Addio."

2 Some Indoor and Outdoor Games of the Wabcuaki Indians, Trans. Roy. Soc. Canada, Section 11. 1889. 
nant of a woven tiara. These relics are now in the hands of Dr. Shehan, of Edmunds, Maine. Copper head-bancis have repeatedly been found on the skulls of Mound Indians. When a boy, I myself was present at the work of excavating an Indian burial place on the banks of Charles River, near the end of Maple Street, Watertown. With one of these skeletons a turtle shell was found, which was possibly an old Indian rattle.

One of the most interesting of the selections mentioned is the Song of the Snake Dance, No. 8. Although the ceremonial element has now disappeared from this song, it may be presumed that it originally had a religious importance similar to that of the Snake Dances of the Southwest, since the extent of the worship of the snake among North American Indians is known. The same dance is also celebrated by the Micmacs, having been performed by them during the past year. In both nations, it is generally united with other dances, and seems to be an appendage to the more formal ones.

The general impression among the Passamaquoddies is that this dance never had a sacred character. The name is said to have been derived from the sinuous course of the chain of dancers, and from its resemblance to the motion of a snake. While there is noth ing to prove that it is a remnant of an ancient snake worship, still it is natural to presume that such is really the case. There are several tales relating to the manner in which men were turned into rattlesnakes, and how the noise of the rattlesnakes has its lineal descendant in the rattles of the dancers. The Indians told me of several songs used for snake dances, but in those which were sung I think I detected the same music, and am confident that the words as given occur in most of them. The discord at the end of the first line is also a feature of the snake dances which I have heard. ${ }^{1}$

The dance is performed at weddings and other festive occasions. It is not used alone, but only with others, and, as I am told, is employed at all times of festival.

SNAKE SONG.

The words of the first strain are as follows :Wăy' ho yārhnie, way ho yārhnie.

The words of the second strain are as follows :-

1 I myself have never witnessed the snake-dance. The description which follows was obtained from Mrs. Brown, who has seen it performed twice, as well as from Peter Selmore, Noel Josephs, and other Indians who have frequently taken part in it. The song was recorded on the phonograph from the lips of Jo:ephs, who is recognized by the Indians themselves as onc competent to sin. the song. Josephs told me that he remenbered when this and other dances took place in a large wigwan made of bark. 
Hew nay ie hâh, hew nXy'y ie hāh, hew nắy ie hāh,

Hew nay ie hah, hew nay ie hāh, hew nay ie häh.

When the strain changes from the first to the second, the words 10 yar' $/ 6$ ne become a discord like noy $\bar{a}$ h.

The first part of the song is sung alone by the conjurer, as he moves about the room in scarch of the snake. In the second part all in the chain of dancers join in with him in the song. The description of the song in l'assamaquoddy, including the invitation to lake part in the dance, is given on the first part of the cylinder. Calls to the assembly to join in the dance are interpolated in the second strain.

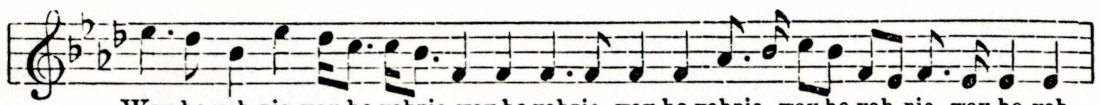

Way ho yah-nie, way ho yahnie, way bo yahnie, way ho yahnie, way ho yah-nie, way ho-yah.

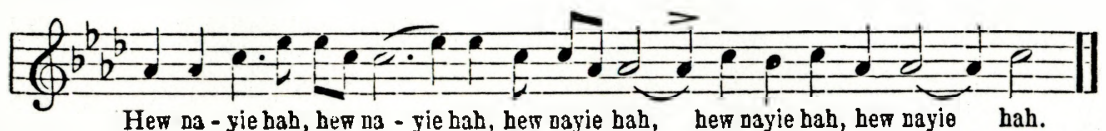

The leader or singer, whom we may call the master of the ceremony, begins the dance by moving about the room in a stooping posture, shaking in his hand a rattle made of horn, beating the ground violently with one foot. He peers into every corner of the room, either seeking the snake or inciting the on-lookers to take part, meanwhile singing the first part of the song recorded on the phonograph. Then he goes to the middle of the room, and, calling out one after another of the auditors, seizes his hands. The two participants dance round the room together. Then another person grasps the hands of the first, and others join until there is a continuous line of men and women, alternate members of the chain facing in opposite directions, and all grasping each other's hands. The chain then coils back and forth and round the room, and at last forms a closely pressed spiral, tightly coiled together, with the leader in the middle. At first the dancers have their bodies bent over in a stooping attitude, but as the dance goes on and the excitement increases they rise to an erect posture, especially as near the end they coil around the lcader with the horn rattles, who is concealed from sight by the clancers. They call on the spectators to follow them, with loud calls mingled with the music: these cries now become louder and more boisterous, and the coil rapidly unwinds, moving more and more quickly, until some one of the dancers, being unable to kecp up, slips and falls. Then the chain is broken, and all, with loud shouts, often dripping with perspiration, return to their seats. ${ }^{1}$

1 The last part of this dance somewhat resembles a play among boys, known as "Snap the whip." 
In this dance all present take part; it always occurs at the end of the Passamaquoddy dances, though it may be followed by a dance of the Micmacs, or other foreign Indians. There was, when last presented, no special dress adopted for the snake-dance, and the horn rattle is used also in other dances. It scems probable that every. thing used in the old times has disappeared, with the exception perhaps of the last-named implement, yet the song resembles closely that of the olden time. The invitations to dance are possibly introduced, and the boisterous finale may be of modern date. There is recorded also on the phonograph, with the song, the invitation to the dance in the Passamaquoddy language. An invitation is extended to all to come to the dance. It is a proclamation that there will be a good time, much to eat, "Indian dances," snake dance, and Micmac dances. The shell of the turtle was used in old times for a rattle, in place of the horn, and in a story of the origin of the rattlesnake the conqueror is said to use a rattle of this kind. In the $\mathrm{Zuñi}$ dances, and in the Moqui snake-dance, a turtle rattle is tied to the inside of the left leg. The rattle, carried in the hand by the Moqui snake dancer, is a gourd, but the Passamaquoddies seem to fincl the horn better adapted for their purpose. The almost universal use of the rattle among the Indians in their sacred dances is very significant. The meaning of the snake song is unknown to the Indians who sing it. The words are probably either archaic or remnants of a sacred language or mystic words of an esoteric priesthood.

The Indian dances held in honor of the chief (governor) and other officers continued for several days. On the first night the newly elected chief sang a song complimentary to the food, thanking the tribe, greating the past governor, etc. Noel Josephs, at the last celebration, sang this song by proxy, as the newly elected chief could not sing. When sung by proxy, the song is called by another name than when sung by the person elected. This song is preserved on one of the cylinders.

\section{TRADE DANCE.}

I have been told that there is an old custom among the Micmacs, still remembered by many now alive, which is probably a remnant of a ceremony with which was connected an old dance. To this custom is given the name of the "Trade Dance," for reasons which will appear. The account of the custom was given by Peter Selmore, who witnessed it not many years ago. It is said to be more common among the Micmacs than among the Passamaquoddies.

The participants, one or more in number, go to the wigwam of another person, and when near the cntrance sing a song. The leader then enters, and, dancing about, sings at the same time a con- 
tinuation of the song he sang at the door of the hut. He then points out some object in the room which he wants to buy, and offers a price for it. The owner is obliged to sell the object pointed out, or to barter something of equal value. The narrator remembers that the dress of the participants was similar to that of the Indians of olden times. He remembers, in the case of women, that they wore the variegated, pointed cap covered with beads, the loose robe, and leggings. The face of the participant was painted, or daubed black with paint or powder.

This song is recorded on cylinder 17 .

The singer told me, and I can well believe it, that the song is very ancient. I have little doubt that in this ceremony we have a survival of dances of the olden times, when they assumed a significance now either wholly lost or greatly modified.

It is not without probability that the songs sung as ancient songs may have modern strains in them, but as a general thing I think we can say that they are authentic. I do not think I draw on my imagination when I say that one can detect a general character in them which recalls that of Western Indians. In order to experiment on this, I submitted the records to a person who had heard the songs of the Plain Indians, and who did not know whether the song which she heard from the phonograph was to be Indian or English. She immediately told me correctly in all cases which was the Indian, although she had never before heard the Passamaquoddy songs.

The folk stories of the Passamaquoddies are but little known to the young boys and girls of the tribe. It is mostly from the old and middle-aged persons that these stories can be obtained. I was told by one of these story-tellers that it was customary, when he was a boy, for the squaws to reward them for collecting wood or other duties with stories. A circle gathered about the fire after work, and listened for hours to these ancient stories, fragments no doubt of an ancient mythology, upon which possibly had been grafted new incidents derived by the Indians from their intercourse with the various Europeans with whom they had been brought in contact.

\section{WAR SONGS.}

I succeeded in getting upon the phonograph several war songs, typical of a large number known to the Passamaquoddies. The words of many are improvised, though there is no doubt that the tunes are ancient. The words of one of these songs are given below.

I will arise with tomahawk in my hand, and I must have revenge on that nation which has slain $m v$ poor people. I arise with war club in my hand, and follow the bloody track of that nation which killed my people. I will sacrifice my 
own life and the lives of my warriors. I arise with war club in my hand, and follow the track of my enemy. When I overtake him I will take his scalp and string it on a dong pole, and I will stick it in the ground, and rily warriors will dance around it for many days; then 1 will sing iny song for the victory over my enemy.

$$
\text { "M' TOULIX." }
$$

Passamaquoddy Indians are believers in a power by which a song, sung in one place, call be heard in another many miles away. This power is thought to be due to $m^{\prime}$ toulin, or magic, which plays an important part in their belief. Several instances were told me, and others have published similar observations. Leland, in his "Algonquin Legends of New England," pp. 517, 5 I8, gives a weird account of an Indian who was so affected by $m$ ' tonlin that he left his home and travelled north to find a cold place. Although lightly clad and bare-footed, he complained that it was too hot for him, and hastened away to find a climate more congenial to his tastes. In this account one is led to believe that the man was insane, and that to the Indian insanity is simply the result of ' $m$ ' toulin.

\section{THE ORIGIN OF THE THUNDER-BIRD.}

In a very interesting paper of $A$. F. Chamberlain, on "The Thunder-Bird among the Algonquins," in the "American Anthropologist," January, 1890 , reference is made to the belief in this being among the Passamaquoddy Indians. On my recent visit to Calais I obtained from Peter Selmore a story of the origin of the ThunderBird, which is different from any mentioned by Leland. This story, I regret to say, I was unable to get on the phonograph.

A story of the old times. ${ }^{1}$ Two men desired to find the origin of thunder. They set out and travelled north, and came to high mountains. These mountains drew back and forth, and then closed together very quickly. One of the men said to the other, "I will leap through the cleft when it opens, and if I am caught you can follow and try to find the origin of thunder." The first one passed through the cleft before it closed, and the second one was caught. The one that went through saw, in a large plain below, a group of wigwams, and a number of Indians playing ball. After a little while these players said to each other, "It is time to go." They went to their wigwams and put on wings, and took their bows and arrows and flew away over the mountains to the south. The old men said to the Indian, "What do you want? Who are you ?" He told his mission, and they deliberated what to do. Finally they took him and

1 The Zuñi folk-tales always begin with a sinilar introduction. which may be translated. "In the time of the ancients." The Passamaquoddies often end a story by the words which, being translated, mean "this is the end." The same occurs in other Indian stories. 
put him in a mortar and pounded him up so that all his bones were broken. Then they took him out and gave him wings and a bow and arrows, and sent him away. They told him he must not go near the trees, for if he did he would go so fast that he cuuld not stop, but would get caught in the crotch of a tree.

He could not get to his home because the bird Wochowsen blew so hard that he could make no progress against it. As the Thunder. Bird is an Indian, the lightning from him never strikes one of his kind. ${ }^{1}$

This is the same bird one of whose wings Glooscap once cut when it had used too much force. There was for a long time, the story goes, no moving air, so that the sea became full of slime, and all the fish died. But Glooscap is said to have repaired the wing of Wochowsen, so that we now have wind alternating with calm.

\section{BLACK CAT AND THE SABLE.}

The translation of the following tale of Pogump, or Black Cat and the Sable, was given me by Mrs. W. Wallace Brown. ${ }^{2}$ The original was told into the phonograph in Passamaquoddy by Peter Selmore, in the presence of Noel Josephs. A bark picture of Pookjinsquess leaving the island, representing the gulls, and Black Cat on the back of the Snail, was made by Josephs. A copy of this picture is given at the end of this paper.

Mrs. Brown tells me there is a story which accounts for the hump on the back of Pookjinsquess, as follows: While leaning against a tree, some one cut off the tree above and below her shoulders, and she consequently carries the hump on her back.

Cooloo, the great bird that overspreads all with his wings, was a chief. His wife was named Pookjinsquess. The Sable and the Black Cat went in a stone canoe to a place where they make maple sugar. In this journey they were lost, and separated from each other. Sable in his wanderings came to a peculiarly shaped wigwam. He went in and found within a large Snake. The Snake said he was glad the Sable had come, as he was very hungry. The Snake told him to go into the woods and get a straight stick, so that when he pierced him he would not tear open his entrails. Sable then went out and sang in a loud voice a song which he hoped his

1 The wind (Wochowsen) is represented as resisting the Thunder-Bird. According to Chamberlain and Leland. "thunder beings are always trying to kill a big bird in the south." It is said by the Passamaquoddies that Wochowsen is the great bird which overspreads all with his wings and darkens the sky. Often when he passes by, the glare of the bright sun is ample to blind them.

2 The version gives only the incidents as remembered, and can hardly be called a translation, 
brother the Black Cat would hear and come to his aid. ${ }^{1}$ The Black Cat heard him and came to him. Then the Sable told the Black Cat the trouble he was in, and how the Snake was going to kill him. The Black Cat told Sable not to be afraid, but that he would kill the big Snake. He told him that he would lie down behind the trunk of a hemlock tree which had fallen, and that Sable should search out a stick that was very crooked, obeying the commands of the big Snake. When he had found a stick, he should carry it to the Snake, who would complain that the stick was not straight enough. The Black Cat instructed Sable to reply that he would straighten it in the fire, holding it there until the steam came out of the end. ${ }^{2}$ While the Snake was watching the process of straightening the stick and the exit of the steam, Black Cat told Sable that he should strike the Snake over the head. The Sable sought out the most crooked stick he could find, and then returned to the wigwam where the Snake was. The Snake said the stick was too crooked. The Sable replied, "I can straighten it," and held it in the fire. ${ }^{3}$ When it was hot he struck the Snake on the head and blinded him." The Snake then followed the Sable, and, as he passed over the hemlock trunk, Black Cat killed him, and they cut him in small fragments. Black Cat and Sable called all the animals and birds to the feast; the caribous, wild horses, and swift animals and birds were first to arrive at the feast. The Turtle was the last, and got only the blood. Then the Black Cat and Sable returned home to Cooloo, whose wife was Pookjinsquess. She thought she would like to have for her husband Black Cat if she could get rid of Cooloo. But Black Cat offended Pookjinsquess and made her angry. To make way with him she invited him to go with her for gulls' eggs. She took him across the water in a canoe to an island which was very distant. There they filled baskets with eggs and started home in the cance. A large, very beautiful bird flew over them. They both shot their

1 Probably Sable had a 'm' toutin, or magic power, and his song was heard by Black Cat, although miles away beyond hills and mountains.

2 Evidently to excite the curiosity of the Snake.

- The fire was outside the wigwam, and the Snake put his head out of the wigwam, when he was struck. Possibly the Snake watclied the process of straightening the stick through curiosity, and was off his guard.

1 In another story which was told me, Glooscap turned the eyes of the Snake white in the following nanner:-

"Once on a time Glooscap was cooking something in his wigwam, and the Snake wished to see what it was. So the Snake crawled up the outside of the wigwam and looked down through the snoke-hole into the cooking vessel. But Glooscap, who was stirring the pot of cooking food, held in his hand a great ladle. He noticed the Snake peering in at the smoke-hole, and, filling the bowl of the ladle full of the hot food, threw it into the eyes of the Snake. From that time the eyes of the Snake have been white." 
arrows at it. The bird fell, and Black Cat jumped into the water to get what they had shot. When he got to where the bird fell he could not find it. Pookjinsquess went off, singing as she went the following song, which has been written out from the phonographic record by Mr. Cheney, and left Black Cat on the island.
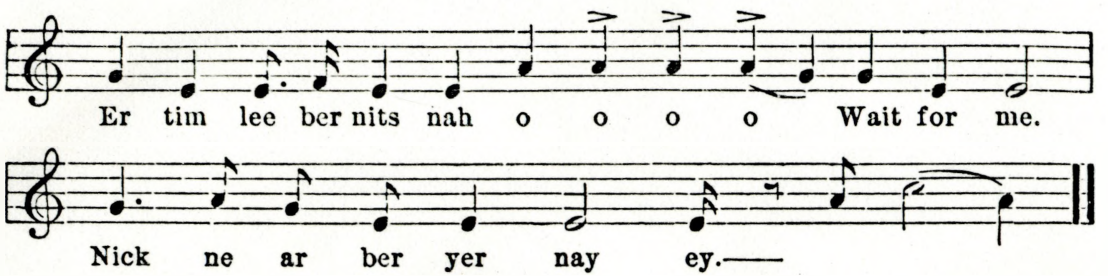

I think there are internal evidences of the antiquity of this song, although the English sentence, "Wait for me," shows the modern character of certain of the words. This sentence seems to supply the place of unknown Indian words. Several Indians assured me that the song was old. According to Leland, Pookjinsquess sang the following words when she left Rlack Cat : -

Niked ha Pogump min nekuk

Netsnil sagamawin!

Which he translates, -

I have left the Black Cat on an island;

I shall be the chief of the Fishers now.

The best I can make out of the phonographic record given me by Peter Selmore of the words which she sang is, -

$$
\begin{aligned}
& \text { Er tin le ber nits nah }>0>0 \\
& \text { Wait for me. } \\
& \text { Nick ne ar ber yer hay ey. }
\end{aligned}
$$

The second line sounds like the English "Wait for me," but is not distinct. The end of the first line is violently explosive. The third line ends in a word expressive of strong fecling, possibly revenge.

In a version of this story by Leland, Pookjinsquess leaves Black Cat on the island, and paddles away, singing songs. In his story; Black Cat was carried off from the island by the Fox, who swam out to get him.

Black Cat called to the gulls to defile Pookjinsquess with their dung. They flew over her, and as she looked up they covered her face with bird-lime. 'They then burst out in a laugh, which they still have, when they saw how changed her face was.

1 According to the narrator, the bird that did this was a very large one. Pos. sibly it was Cooloo, the offended husband of Pookjinsquess. 
Black Cat wandered about the island, until at last he found a wigwam of the grandfather, the "Morning Star," who told him he was on a very dangerous island. He told him it was the habit of the Great Beaver to destroy every one who came to the island."

He told the Black Cat to climb a tree, and when he needed help to call out for him. Night coming on, water began to rise about the base of the tree, and the Giant Beaver came and began to gnaw at its base. The friendly ants ${ }^{2}$ tried to keep the tree upright, but the water continued to rise and the Beaver kept on gnawing. Then the Black Cat in his sore dilemma called out, "Grandpa, come !" The grandfather responded, "I am coming; wait till I get my moccasins." The water rose higher. Again Black Cat called out, "Come, grandpa, come !" "I am coming," his grandfather said ; "wait till I get my cap." Again Black Cat called, "Hurry, grandpa!" "Wait until I get my pipe," said the grandparent. But the waters had reached him. The tree swayed to and fro. "Come, grandpa, come!" said Black Cat for the last time. Then he said, "I am coming; wait till I open my door;" and then he opened the door of his wigwam and the Morning Star came forth, the water began to recede, and the Beaver swam away. ${ }^{3}$ Then Black Cat's grandfather told him to come down, and he would send him over the water to the other shore on the back of the Wewillemuck. Black Cat thought that Wewillemuck was too small to carry him over, but his grandfather told him to seat himself between his horns, and when he wished Wewillemuck ${ }^{4}$ to go faster he should tap him on the horns. The grandfather then gave his grandson a small bow and arrows. and put him on the snail's back between his horns.

As they were crossing the channel, Wewillemuck said to the Black Cat, "When we get near shore tell me." But Black Cat gave Wewillemuck a sharp rap on the horns, and the snail jumped forward and went so far that both went a far distance inland.

1 Quahbet, or the Giant Beaver, was not on the best of terms with Black Cat, for Glooscap had slain many of the beavers, whose bones still exist, and are of giant size. This hatred probably arose, says Leland, from the time when Quahbeetsis, the son of the Beaver, inspired Malsumsis to kill Glooscap.

2 The ants assisted Black Cat in many ways. They were also friendly to Leux, and on one occasion are said to have gathered the bones and fragments of the "Merry God" together and restored his life. Whether in the present instance they tried to keep the tree upright by piling the earth about its trunk or not, the narrator does not say.

- Possibly the gnawing of the Beaver is the ripple of the waves around the base of the tree.

4 Mrs. Brown has identificd Wewillemuck as the snail. Some of the Indians say that it is a large lizard like an alligator. The hark picture of this creature, made by Noel Josephs, is that of a nondescript difficult to identify. 
Wewillemuck said, "Why did you not tell me we were near the land? Now I cannot get back to the water again." But Black Cat took his small bow and arrows, and with them carried Wewillemuck back to the water. So pleased was he that he said, "Scrape from my horns some fine dust, and, whatever you wish, put this powder upon it and it is yours." So Black Cat scraped off some powder from the horns of Wewillemuck.

The Raven was told to build a wigwam for Cooloo, who was chief. Pogump (Black Cat) went to see the chief, and killed him with the powder. Black Cat went to see Pookjinsquess; he scattered a ring of powder around her wigwam, and then set it on fire. It blazed up and ignited the wigwam, burning up the old woman Pookjinsquess, whose ashes, blown about by the winds, made the mosquitoes." 1

Leland, in his version of this story, represents the Black Cat as identical with Glooscap, ${ }^{2}$ and the Sable as a boy who had a flute by which he could entice to himself all the animals. The story of the sticks is similar, but the cutting up of the serpent is not mentioned. He says that Black Cat, who is preparing his arrows, and will return and destroy all, is Glooscap, who in another story kills the Snake, cuts him in fragments, and invites all the animals to eat him. The Turtle, the grandfather (adopted), arrives last, and only gets the blood for his share.

\section{A STORY OF LEUX.}

A story of the old time. In winter, while travelling, Leux met a number of wolves, which were going in the same direction that he was. At nightfall the old wolf built a fire and gave Leux supper. He gave him skins to cover himself while he slept, but Leux said that the fire was so warm that he did not need or wish a covering. At midnight Leux awoke and was almost frozen with cold. The next morning Leux was obliged to part with the wolves. ${ }^{3}$

The old wolf said, "How far are you going?" Leux answered, "Three days' journey." The wolf said then, "I will do for you the

1 In this manner he obtains his revenge. Dr. Boas tells me he has heard a similar story of the origin of the mosquitoes on the West Coast.

2 Mrs. Brown writes me that the Black Cat referred to is not identical with Glooscap. "There were very many of these mythological personages," she says, "who were able to do things as wonderful as Glooscap, but they were not of his nature. He worked for good, they for selfish purposes."

Mr. Leland's work exhibits throughout want of exactness in recording just what the Indians told him. It is in deductions and explanations that errer is liable to arise. A story made up from the recital of several Indians is likely to exhibit their attempts to explain doubtful parts of the story.

- It would seem, from Leland's account, that the wolf admired Leux greatly because he cared so little for the cold or their care. 
very best thing I can. I will give you three fircs, one for each night." The wolf told him to gather some dry wood, put it in a pile, jump over it, and it would burn. ${ }^{1}$

Leux parted from the wolf, and as soon as he was out of sight he thought he would try to make a fire as directed by the wolf, remarking that he did not think it would burn. So he gathered some dry wood, made a little pile, and jumped over it, as he had been directed. The wood was ignited, as the wolf had predicted, much to the surprise of Leux. Leux then put out the fire. After walking a short distance he kindled another in the same way. This he put out as bafore, and at noon tried again, kindling the fire as before and putting it out immediately after. Now when night came Leux made a camp and collected a pile of good dry wood and jumped over it, as he had done previously, and as he had been directed by the wolf. But this time the wood did not burn. He repeatedly jumped over the wood, but in vain. The wood gave off a cloud of smoke, but no blaze appeared. That night it was bitter cold, - so cold that Leux was nearly frozen to death. ${ }^{2}$

One day two young girls (in Leland's account the two girls are weasels) were walking along, and $\mathrm{k}^{\prime}$ Cheebellock came to them and carried them to his home in another world high up in the sky. The girls became homesick in the strange place, and every day they longed more and more to get back to the earth. Every day they cried for their homes. At last $\mathrm{k}^{\prime}$ Cheebellock offered to carry them back to the earth, and took them up to transport them to their native land. But k'Cheebellock's wings were so large that he could not get to the ground on account of the high trees. So he left them in the top of a very high hemlock in the midst of the forest. ${ }^{3}$

The girls could not get down out of the tree. As time passed on, after a long time they saw a young man walking in the woods. They cried out to him to come and take them down. The first time they called, the young man did not look up. Now this man was Leux: they called again, and he replied that he was very busy building a road [trail], and he said he could not take them down he was so occupied. After a long time the girls saw Leux pass by again, and

1 It was possible that the wolf gave him some charm or medicine with which to accomplish this.

2 The above story is told substantially as here given by Leland, but with many additions. The source from which Leland obtained his account is not given. The account which I give is from Noel Josephs. In Leland's account Leux froze to dealh.

${ }^{8}$ Notice, also, that the thunder-birds were not able to approach the trees, and the Indian who was turned into a thunder-bird was warned not to approach the forest, for he moved so rapidly that he would get caught in the crotch of a tree. 
they begred him to take them down from the tree. This time Lcux replied that he would take them down if one of them would consent to become his wife. To this they agreed.

Now these girls had their hair tied with long shreds of eelskins. They took off these strings, which bound their hair behind, and securely tied them in hard knots on the top branches of the tree upon which they were. Leux climbed the tree and brought the girls down safe and sound. He then demanded one of them for his wife. ${ }^{1}$

But the girls said, "First, it is necessary for you to untie and bring down our hair bands for us." Leux climbed the tree to get the eelskin hair bands, but they had tied them so securely that it took him a long time to loosen the knots. When he came down the girls had built a large and beautiful wigwam. They then made Leux blind ${ }^{2}$ [how, the narrator did not know].

Then the maidens call out to him, and now one and now the other invites him to come to her. As he follows their voices one of them leads him to fall into the water, and the other makes him stumble on porcupine quills. Exhausted, Leux then goes to sleep, wearied out with his exertions, but when he awoke the maidens had vanished.

The story of the Indian maids who were loved by k'Cheebellock, the spirit of the air, is told in another way by Leland, although that part of the story which pertains to Leux and the hair bands is the same in both accounts. In Leland's account we have a beautiful legend, Micmac and Passamaquoddy, in which two maids, called the weasels, are loved by the stars, not by $\mathrm{k}^{\prime}$ Cheebellock. It is interesting also to note that the hair bands in this variant of the story were of eelskin, a fact which is not brought in Leland's account. $\mathrm{k}^{\prime}$ Cheebellock is a superhuman deity of the Passamaquoddies, and is represented as a being without body, but with heart, head, wings, and long legs. He is stronger than the wind, and is the genius of the air. k'Cheebellock has sometimes been confounded with Kewok, but Kewok is the cannibal deity, or a cannibal giant. He is said to have a heart of ice, and to afflict the Indians in many ways. It is he who tears the bark from the wigwam, and who frightens men and women. Kewok is the being in whom a Norse divinity has bcen recognized by one or two well-known scholars.

In olden times the hair of women was tied with hair strings which were sccurely bound to a flat plate on the outside. This plate was formerly of shell, or later of metal. To this hair string was ascribed

I It would be more in accord with the Indian words to say "have one of them" instead of "have one of them for a wife."

2 The wigwam may have been so dark that he could not see anything, or perhaps he was blinded by his admiration for the girls. 
certain magic powers, especially in love affairs, and the possession of it was a potent spell.

HOW A MEDICINE MAN WAS BORN, AND HOW HE TURNED MAN INTO A TRFE.

A story of old times. There was once a woman who travelled constantly through the woods. Every bush she saw she bit off, and from one of these she came to be with child. She grew bigger and bigger until at last she could travel no longer, but built a wigwam near the mouth of a stream. The woman gave birth to a child in the night. She thought it best to kill the child, but did not wish to murder her offspring. ${ }^{1}$

At last she decided to make a canoe of bark, and in it she put her child and let it float down the river. The water of the river was rough, but the child was not harmed, or even wet. ${ }^{2}$ It floated down to an Indian village, and was stranded on the shore near a group of wigwams. A woman of the village found the baby on the shore and brought it to her home. Every morning, after the baby had been brought to the place, a baby of the village died. The Indians did not know what the matter was until they noticed that the waif which the woman had found in the bark on the river bank went to the river every night and returned shortly after. A woman watched to see what this had to do with the death of the babes, and she saw the child, when it returned to the wigwam, bring a tongue of a little child, roast and eat it. Then it laid down to sleep. The next morning another child died, and then the Indian knew that its tongue had been cut out. It was therefore believed that the strange child had killed the baby. They deliberated as to what they should do with the murderer. Some said, cut him in pieces and cast the fragments into the river. Others said, cut him up and burn the fragments. This, after much consultation, they did. They burnt the fragments of the child until nothing but the ashes remained. Everybody thought it dead, but the next morning it came back to camp again, with a little tongue as before, roasted and ate the morsel. The next morning another child was found to have died the night before. After the weird child had roasted and eaten the tongue of its victim he laid down to sleep in the same place he had laid before he had been cut up into fragments and cremated. But in the morning the child said

${ }^{1}$ By combining this story with some given by Leland it would seem that the child was Glooscap. If that is so, this is the only account in Passamaquoddy lore in which his parthenogenetic origin is traced. Mrs. Brown insists, however, that the medicine nan was not Glooscap.

2 The resemblance of this story to the tale of Moses is very great. Whether or not it is derived from the cary teaching of the church through Catholic priests, or from still earlier Norse legends, I leave others to decide.

vol. III. - vo. II. 
that it would never kill any more children. He had now, in fact, become a big boy. He said he would take one of his bones out of his side. This he tried to do, and as he did it all the bones came out of his body at the same time. Then he closed his eyes by drawing his fingers over his eyelids so that his eyes were hidden (not necessarily blind). He could not move, because he had no bones and had grown very fat. He became a great medicine man, and told the Indians that whatever they asked of him he would grant them. Then the Indians moved away from the place and left the medicine man behind in a nice wigwam which they built for him. But they were accustomed to go back when they wished anything, and to ask the conjurer for it. The Indians used to go to him for medicine of all kinds. When he granted their request he said, "Turn me over and you will find the medicine under me." 1

Once upon a time a young man who wished the love of women went to him and asked for a love potion. The old man said, "Turn me over." The young man turned the conjurer over and found under him an herb. The old man told him he must not give this away or throw it away. The young man went home to bis wigwam. On his return home all the women of the place followed him, everywhere and at all times. He longed to be alone, and did not like to have the women so much about him. At last he was so much troubled by them that he went back to the conjurer and gave back the medicine to the medicine man, who took the herb, and the young man went away without it. Another man went to the conjurer for medicine. The old man said, "What do you want ?" He said, "I want to live as long as the world stands." The old man said the request was hard to grant, but he would try to answer it. The conjurer, as was his wont, said, "Turn me over," and underneath his body was the herb. Then the conjurer told the man who wished to live forever to go to a place which was bare of everything, so bare indeed that it was destitute of all vegetation, and to stand there. He pointed out the place to him. This the man did, and, looking back at the conjurer, branches grew out all over him, and he was changed into a cedar tree. He is useless to every one, and there he will stand forever.

The first part of this story strongly reminds one of the story of Moses, and may have been due to contact with Europeans. It is to

1 Dr. Rand (American Antiquarian, p. 8, vol. xii. No. I) mentions a personage (Koolpejot) as " rolled over by means of a handspike." Ile is a great medicine man: he has no bones, always lies out in the open air, and is rolled over from one side to the other twice a year, during spring and fall. He adds that an intelligent Indian once suggested that this was a figurative representation of the revolution of the seasons. 
be remarked that the mother of the child became pregnant by eating an herb. The child is therefore parthenogenctic. According to Leland, the medicine man who turned the man into a cedar tree is Glooscap. Glooscap performed many such miracles, as in the case of the story of the animals. In another story the father of Glooscap is mentioned as a being who lives under a great fall of water down in the earth. His face is half red, and he has a single eye. In another he can give to any one coming to him medicine to grant him whatever he wishes, and in still another Glooscap is now sharpening his arrows way off in some distant place. He will return to earth and make war.

"On whom will he make war?" "He will make war on all, kill all : there will be no more world; world all gone. Dunno how quick, - mebbe long time : all be dead then, mebbe - guess it will be long time."

"Are any to be saved by any one?" "Dunno. Me hear some say world all burn up some day; water all will take fire. Some good ones be taken up in good heavens, but me dunno; me just hear that. Only hear so." '

In their stories the Passamaquoddies tell the old stories as true; but they speak of other stories as what they hear. The part of the above account, of the return of Glooscap and the destruction of the world, they say is true. The last portion shows its modern origin in the statement that they hear that it is so.

The stories of the birth of Glooscap, ${ }^{2}$ his power to work miracles, and his ultimate return to earth, are very suggestive.

The belief of the Indians in a Great Spirit is a figment of the imagination on the part of the whites. It is now extremely difficult to discover what the original belief of the Passamaquoddies was, as they are now Christianized and have been for many years.

From a scientific standpoint much has been lost by this change. There are several customs which are undoubtedly modifications of older observances which they probably replace. That these customs are secondary modifications, their general character seems to demonstrate. Still they have certain Indian features, and as such merit record. There are doubtless certain religious observances which have been changed by the infuence of the whites. If these were rightly interpreted they might tell some very interesting story of the ancient beliefs of this people, but many of these observances have been so modified that their meaning, if they have any, is wholly obliterated.

Among these might be mentioned a common burial custom, an

1 Quoted from Leland's $A$ lgonguin Leginds.

According to Leland's story. 
account of which has never been recorded. I am informed by Mrs. Brown that when an Indian dies a gun is fired. The coffin is enveloped with fine white sheeting, and cords are tied around the sheeting to keep the cotton in place. When the coffin is lowered into the grave the cords are removed, and the cotton is given to the gravedigger. Possibly this custom may have been derived from some older one, or may have originated from contact with the whites. The mode of burial in coffins and the use of cotton shecting are certainly modern customs, but may be modifications of some older ceremonial when other material was used.

The counting-out rhyme which is given on the cylinder is as follows :-

Hony, kee bee, lã ã-weis, ag-les, huntip.

The inflection on the last word is always a rising one. This is especially true on the last syllable of the last word, "tip." The counting out is not very different from that of white children. They all place two fingers of each hand in a circle; the one who repeats the doggerel, having one hand free, touches each finger in the circle saying, Hony, kee bee, lä ä-weis, ag-les, huntip. Each finger that the huntip falls on is doubled under, and this is repeated again and again until there are but three fingers left. The persons corresponding to these start to run, and the one caught has to play as Squaw-oc-t' moos. ${ }^{1}$ To the Indian mind "counting out" has a significance, and even the simple huntip is a magic word, bringing good luck, as it lessens the chance of being squaw-oc-t'moos." ["Journal of American FolkLore," vol. iii. No. 8, pp. 7I, 72 ]

One of the songs, said to be a salutation, which was sung on the cylinders, has been written out from the phonograph by the late Mr. S. P. Cheney. The words, as nearly as I can make them out, are as follows :-

T'wã too boo hen ee too boo ho [to be way] bla

Tel ey wees ee lu

Hoi kay yu kar, heno yah ha,

Kaye yu kar, hen o yar-hah,

Kay yu kar, hen o yah-hah, kay yu kar, hen o yar-hah.

The first two lines are sung first to the upper staff, then repeated to the music on the second, which differs somewhat from the first. Then follows the third and fourth lines, which are sung to the third staff, and repeated with slight variation from the fourth.

1 The word "squat" in Passamaquoddy means fire. Mrs. Brown spells the name of the swamp woman as follows: Squazw-oc-t'moos. The $a$ is very long, and possibly can be best represented by aw. 


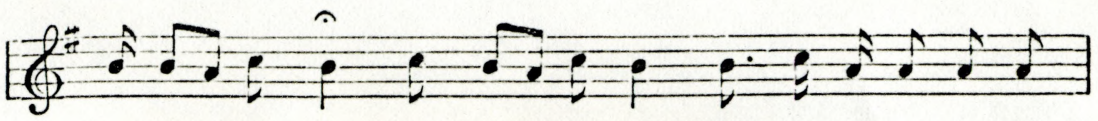

T'wā too boo hen ee too boo ho bla tel ey wees ee lu
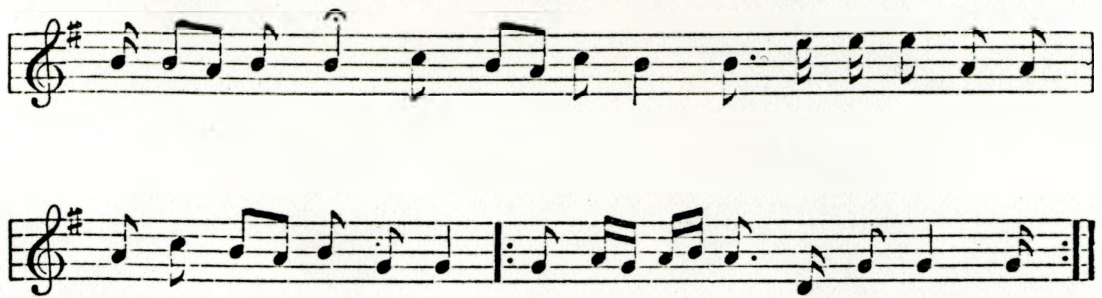

Hoi kay yu kar, hen - o yah ha, kaye yu kar hen o yar - hah.

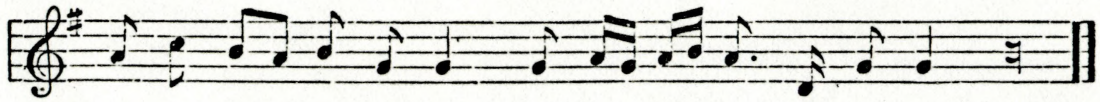

The question of whether the Indians originally had characters to designate tones has been discussed by Theodor Baker (" Ueber die Musik der Nord Amerikanischen Wilden"). Although the Micmacs s:emed to have had an elaborate system of hieroglyphics ${ }^{1}$ to designate sounds, neither they nor their immediate neighbors, according to Vetromile, had characters to designate tones. The songs were probably committed to memory, and possibly on that account were often somewhat modified.

The cylinder with Passamaquoddy woris and the English equivalents has the following records, which I have written down as nearly as I could from the phonograph, and verified by repeating them from my spelling to the Indians. With two exceptions, the Indians were able to understand the word meant, and to give me an English equivalent identical with that originally recorded. I have made these experiments of verification in order to test the capabilities of the phonograph. In the cases where my spelling of the word has failed to convey the sound of the word, the phonograph was perfectly understood by the Indian interrogated. This fact seemed to me to bring out a serious defect in the use of the phonetic method, which may not be confined to me alone. I doubt very much if the Indians could understand many of the words in some of the vocabularies of other Indians which have been published, if the words were pronounced as they are spelled. The records of the phonograph, although of course sometimes faulty, are as a general thing accurate.

1 Pictographic writing, which is so well known among the Micmacs, was also practised by the Passamaquoddies. The sign of the Passamaquoddies is a canoe with two Indians in it and a porpoise. This sign appears on rocks in certain places. The design for the present flag of this tribe is of late conception, and shows the Christian influence. 
When I wrote out the l'assamaquoddy words given below, I was whoily ignorant of their meaning. I wrote them as I heard them on the cylinder, placing at their side the English equivalent. I then pronounced the word to an Indian, and he gave the same English word which I had myself written from the phonograph :-

\begin{tabular}{|c|c|}
\hline \multirow{2}{*}{\multicolumn{2}{|c|}{ or. }} \\
\hline & \\
\hline Wee tin, nose. & Wusquān, elbow. \\
\hline Huk, body. & Kort, leg, \\
\hline K'telobägen, arms. & Qūtque, knee. \\
\hline Sqăt, fire. & Wukum, heel. \\
\hline$K^{\prime}$ tāgen, foot. & Wus quout, liver (heart). \\
\hline $\begin{array}{l}\text { Wittuk, forehead. } \\
\text { (Puks que nor wūk }\end{array}$ & Wee bee, tooth. \\
\hline
\end{tabular}

The object of the above list is simply to show how nearly one can obtain the sound of the word phonetically by the phonograph. It is thought to illustrate a possible use of this instrument.

Vocabularies of Passamaquoddy words have been published, but as a general thing they are very incomplete. Miss Abby Alger, of Boston, has printed a short list of common words and phrases, and in Kilby's "History of Eastport " the Passamaquoddy names of certain localities, rivers, etc., are given.

It is probably impossible to get the same story in all its details from two different Indians. The variations in incidents are very numerous. Consequently the observer who follows me will undoubtedly find a great difference between the tale as I give it and as he hears it. That is to be expected, nor is it probable that these stories admit of absolute accuracy as long as human memory is fallacious. These stories are membra dcjecta of older ones, and, although lineal descendants of ancient tales, are probably more or less modified or changed.

The following are a few of the mythological characters which play a part in many of the stories of the Passamaquoddies. They are all given on one of the cylinders of the phonograph :-

Leux. Mischicf-maker. In certain stories, simple fellow.

Kewok. A formless being with icy heart, and when mentioned regarded as a terrible one.

Pedogiic. Thunder.

Pesok que tuk. Lightning.

Ooargamess. Small beings who live about rocks and chatter in unknown tongue. Have been seen in late times.

lumpingonosis. Water beings.

Kelfhit. A shapeless (medicine) being who is turned over twice each year. Under him are found flowers.

rogumpt. lilack Cat, Fisher.

$k$ Chebollock. The Spirit of the Air. This being is said to be without body, but to have a heart, wings, head, and legs. 
Cadoux. Spirit of Night. Said to have been seen lately. An evil spirit which tears bark from the wigwam, and in many ways frightens the Indians.

pook-jin-squess. The Jug. Called also the toad woman. In some Indian stories spoken of as governor.

Noosagess. $\mathrm{A}$ being associated with the wind.

Square-oc-t'moos. Siwamp woman.

Moushalit. Grandfather.

Glooscap. The beneficent being whose deeds are generally superhuman, and who figures in many heroic tales of the Passamaquoddies. The term as applied to a man is one of contempt. To call a man glooscap, or a woman glooscapess, is to call them liars.

Chematiquess. The big rabbit. There are many tales in relation to Chematiquess. The new one which I have treats of his efforts to escape Glooscap.

Mickemnise. The good fellow. I have also heard the Ouargamiss called Mick. eminn.

Hespens. The raccoon.

Quarbet. The giant beast.

M'Sartoo. The Morning Star.

Consuce. The ancients; said to be the fabricators of stone things. These were the makers of the stone axes or tomahawks which are found in the territory once inluabited by the Passamaquodies.

The accompanying plate illustrates the above mentioned story of Pogump and Pookjinsquess, the original of which was drawn on birch bark by Noel Josephs.

Since the above was written, I have spent some time at Zuñi Pueblo, New Mexico, during which my studies of aboriginal language with the phonograph were continued. While it is too early to state the exact value of the records obtained, it may be interesting to know that I have succeeded in obtaining some important specimens of the songs, stories, and praycrs of this tribe in the course of the summer. The songs of the sacred dances of the Zuñians are particularly adapted to successful recording with the phonograph. Of these there were obtained several so-called $K o$-ko songs, such as are sung in the Kor-kok-slii or rain clances. The song sung at the Ham-po$n e y$, an ancient dance celcbrated evcry eight or ten years by the women, was also obtained from one of the participants. This dance, an elaborate corn-dance, is said to be an ancient ceremony, and is, next in importance to the dedication of the houses, one of the most striking events in the Zunian calendar. The rarity of its performance, and the possibility that when next performed it may be greatly modified, give a unique value to this record.

The most important of the ceremonics of the winter at Zuni Pueblo is undoubtedly the Sha-la-ko, at which certain of the houses to the number of seven, which have been built during the past year, 
are dedicated. The song and prayer of the Shatlit-ko was sung for me into the phonograph by one of the Zunians, who had, as I was told, taken part in the celebration a few years ago.

Among other interesting records may be mentioned the prayer of the hunter to his fetish when on the hunt; and that of the Priest of the Bow, fornerly sung when he went to war with the Navajos. I also obtained a song of the She-vo-la dance, which bears evidence of great antiquity.

I failed to get what I especially desired, viz., a record of the Zuni ritual or history of the tribe. Although repcatedly promised that it should be given, and while at one time I thought that I had obtained part of it, I must acknowledge an utter failure to accomplish what was hoped in this line. The Zuñi epic, so called, is still unrecorded on the phonograph, although at one time I was so confident that I had obtained it, that I stated such to be the fact, and my statement has appeared in print.

There is among the Zuñians an interesting ceremonial for rain, which is observed on the night before the departure of the pilgrims who visit the Sacred Lake for water, as a preparation for the first of the solstitial rain dances. I have been able to obtain the chant and words of this ceremonial, called the Dw-me-chim-che, from one who has taken part in it. The observance is so primitive, and bears so many evidences of antiquity, that a record of the chant has an importance, in the study of the customs of this interesting people, second to none with which I am familiar.

Experience has taught me that records of songs are the best which can be obtained. These are, as a rule, better adapted to the phonograph. Rituals and prayers are repeated in such a low tone that they are, as a general thing, imperfectly reproduced on the wax cylinders of the phonograph. A natural timidity of the Indians with respect to repeating the sacred formulæ, and the absolute fear which some of them have when the records are repeated to them by the phonograph, prevented my obtaining many of these valuable records. Still I have made a beginning, and have obtained enough to demonstrate the value, I think, of the instrument, in the preservation and study of aboriginal folk-lore.

I have prepared an elaborate account of the ceremonies witnessed by me, in many of which the songs, formulx, and prayers of the participants were repeated on the phonograph, and the records themselves will be published as soon as they are carefully worked out.

F. Walter Feroles. 